\title{
The Possibility for Environmental Friendly Recycling of Printed Circuit Boards
}

\author{
Vitomir Premur', Aleksandra Anić Vučinic ${ }^{* 2}$, Dinko Vujevič́3, Gordan Bedeković4 \\ ${ }^{1}$ Department of Environmental Engineering, Faculty of Geotechnical Engineering, University of Zagreb, \\ Hallerova aleja 7, HR-42000 Varaždin, Croatia \\ e-mail: vitomir.premur@optinet.hr \\ ${ }^{2}$ Department of Environmental Engineering, Faculty of Geotechnical Engineering, University of Zagreb, \\ Hallerova aleja 7, HR-42000 Varaždin, Croatia \\ e-mail: aav@gfv.hr \\ ${ }^{3}$ Department of Environmental Engineering, Faculty of Geotechnical Engineering, University of Zagreb, \\ Hallerova aleja 7, HR-42000 Varaždin, Croatia \\ e-mail: dinko.vujevic@gfv.hr \\ ${ }^{4}$ Department of Mining and Geotechnical Engineering, Faculty of Mining, Geology and Petroleum \\ Engineering, University of Zagreb, Pierottijeva 6, HR-10000 Zagreb, Croatia \\ e-mail: gordan.bedekovic@rgn.hr \\ Cite as: Premur, V., Anić Vučinić, A., Vujević, D., Bedeković, D., The Possibility for Environmental Friendly \\ Recycling of Printed Circuit Boards, J. sustain. dev. energy water environ. syst., 4(1), pp 14-22, 2016, DOI: \\ http://dx.doi.org/10.13044/j.sdewes.2016.04.0002
}

\begin{abstract}
The goal of this work is to find a solution for disposal of Vitroplast FR4, a material found in waste printed circuit boards. In this study, the influence of addition of Vitroplast, generated by mechanical treatment of printed circuit boards waste on concrete properties such as compressive strength was investigated in laboratory conditions. By substitution of filler (i.e. sand) in a mass ratio of 5, 10, 15 and 20\% with Vitroplast in concrete mixture, the compressive strength decreased into 57.5, 84.5, 95.0 and 95.9\%. The results of leaching tests have shown that by incorporating Vitroplast in concrete mixtures in a $10 \%$ mass ratio, the elution of arsenic and cadmium is below the limitations prescribed for inert wastes. The studied approach offers the possibility for environmental friendly recycling of printed circuit boards.
\end{abstract}

\section{KEYWORDS}

Printed circuit boards, Recycling, Vitroplast FR4, Concrete production, Waste management, Environmental protection.

\section{INTRODUCTION}

Printed Circuit Boards (PCBs) are important parts of Electrical and Electronic (EE) equipment and presents about 3-6\% of overall amount in it according the data published in literature [1]. Rapid technological development demands evolution of new generation of PCBs which results in constant growth of its production. On the other hand, disuse of EE equipment leads to formation of significant amount of this type of waste which can exceed 20-50 Mt annually around the world [2]. Moreover, PCBs contain copper, gold, palladium and other valuable metals as well as hazardous compounds such as arsenic, lead, mercury, cadmium, beryllium and bromine based retardants. About $30 \%$ mass of PCBs includes wide range of different metals $[3,4]$. That is the main reason for recycling of printed circuit boards. The rest of $70 \%$ of printed circuit boards mass include plastics, ceramics, glass fibres and similar compounds without any significant market value but

\footnotetext{
* Corresponding author
} 
due to the content of brominated flame retardants and incorporated heavy metals it is not appropriate for landfill disposal neither calorific value exploitation, as reported in literature $[5,6]$. The major part of non-metal fraction in PCBs presents composite material Vitroplast. Despite its hazardous characteristics, EE waste, PCBs and non-metal fractions have been mainly disposed on landfills or export into developing countries with the less advanced level of technological treatment or by incineration, according to reported data [7]. Furthermore, disposal of this type of waste can pollute groundwater. Inappropriate incineration of this material could generate toxic compounds such as dioxins.

PCBs have been mainly treated by usual processing technologies such as: size degradation, screening, electrostatic and magnetic or gravitational concentration methods. According to data published in literature $[8,9]$, the complete liberation of metal parts has been achieved by size degradation on $-0.5 \mathrm{~mm}$ class. In the final phase the useful elements have been separated by pyrometallurgical, pyrolytic, hydrometallurgical, vacuummetallurgical and biometallurgical processes [8].

Thermoset resins have small calorific value due to the content of brominated flame retardants. So, in the case of incineration of this type of material a serious problem could present generation of Polybrominated Dioxins and Furans (PBDD/Fs). More advanced PCB treatment technologies have been mainly studied; however due to high cost they are less represented. Numerous studies of PCB treatment possibilities have been performed but mainly on scientific and experimental level. State of the art treatment practice of nonmetal fraction considers pyrolytic processes, blurring, depolymerization in supercritical conditions and using as adsorbents in wastewater treatment processes [10,11], fillers in thermoset resin and thermoplastic mixtures [12], modifiers for highly elastic materials as well as fillers in concrete production [13-15]. Therefore, the development of new product and the establishment of market conditions is a challenging issue for non-metallic material utilization as stated in literature [16]. In order to reduce negative environmental impact of available PCBs treatment technologies, a technology for recycling of PCBs by using ionic liquid was studied [17].

The use of non-metal fractions as fillers in concrete production has been mainly studied in order to encapsulate harmful compounds with the purpose of safe disposal [13].

In this work, the influence of addition of Vitroplast, generated by mechanical treatment of printed circuit boards waste on concrete properties was investigated in laboratory conditions. Incorporation of harmful compounds in concrete mixture was studied. Also, volumetric weight and swelling pressure of concrete prepared was analysed.

\section{MATERIALS AND METHODS}

\section{Technological procedure of Vitroplast separation}

For obtaining Vitroplast from EE waste the following accessories and devices were used: hammer mill, $500 \mathrm{~mm} \times 500 \mathrm{~mm} \times 150 \mathrm{~mm}$ quartering cross, set of round sieves for the sieving of $200 \mathrm{~mm}$ diameter and $40 \mathrm{~mm}$ height, with the gap of $4.0 \mathrm{~mm}, 2.0 \mathrm{~mm}$, $1.0 \mathrm{~mm}, 0.5 \mathrm{~mm}, 0.25 \mathrm{~mm}, 0.125 \mathrm{~mm}$ and $0.063 \mathrm{~mm}$, laboratory shaker for the sieves with $\phi 200 \mathrm{~mm}$, frequency $50 \mathrm{~Hz}$, amplitude 0.1 up to $1.0 \mathrm{~mm}$, technical scale Sauter, measuring range 0 to $1,000 \mathrm{~g}$ with precision of $0.1 \mathrm{~g}$.

\section{Development of probationary bodies}

For preparation of probationary bodies laboratory mixer model Tonindustrie, mold for development of concrete cubes of $1 \mathrm{dm}^{3}$ volume and laboratory scale KERN/ABJ 220-4M were used (Figure 1). In the experiments the sample of vitroplast remained after 
PCB treatment (Figure 2) was used. Two fractions of natural sand of alluvial origin by $4 \mathrm{~mm}$ class (F1) and 8/4 mm class (F2), portland cement and hydrophobic additive Wetmix were incorporated in probationary bodies. Probationary bodies were developed in Laboratory of processing materials, Faculty of Geotechnical Engineering with variation of Vitroplast ratio solely. In all experiments the ratio of filler in concrete exceeded $85 \%$, cement $15 \%$, the ratio of water and cement (w:c) 1:0.6 and the portion of additives $1 \%$ of cement mass. The ratio of $\mathrm{F} 1: \mathrm{F} 2$ was set to be $0.45: 0.55$. For every probationary body, $2.5 \mathrm{~kg}$ of mixture was prepared. Following this prescription, it was tried to prepare concrete mixture as similar as it is prepared on industrial scale for different concrete products production. The ratio of water and cement was chosen on the basis of expertise and has adjusted for conditions of probationary bodies preparations on laboratory scale. Probationary cubes with the edge length of $100 \mathrm{~mm}$ were made according to EN 12390-2:2009 standard [18]. Compression was achieved by mechanical vibration on vibrotable of $50 \mathrm{~Hz}$ frequency, with amplitude of $0.3 \mathrm{~mm}$ in duration of 60 seconds. Probationary bodies were cured in humid chamber.

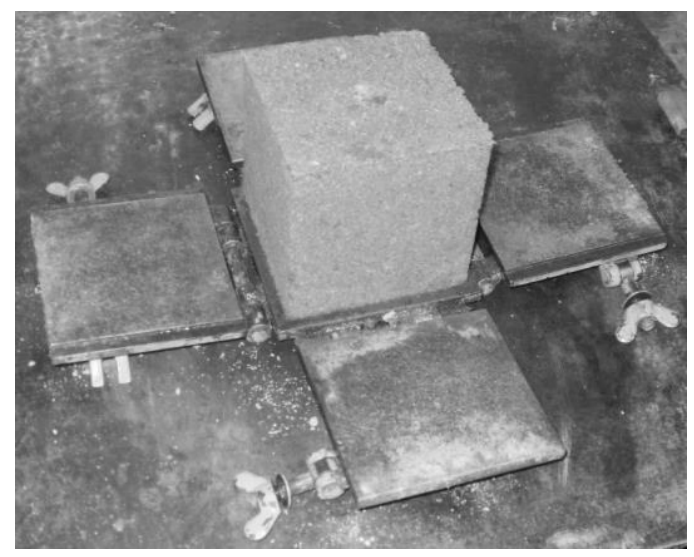

Figure 1. The display of prepared samples

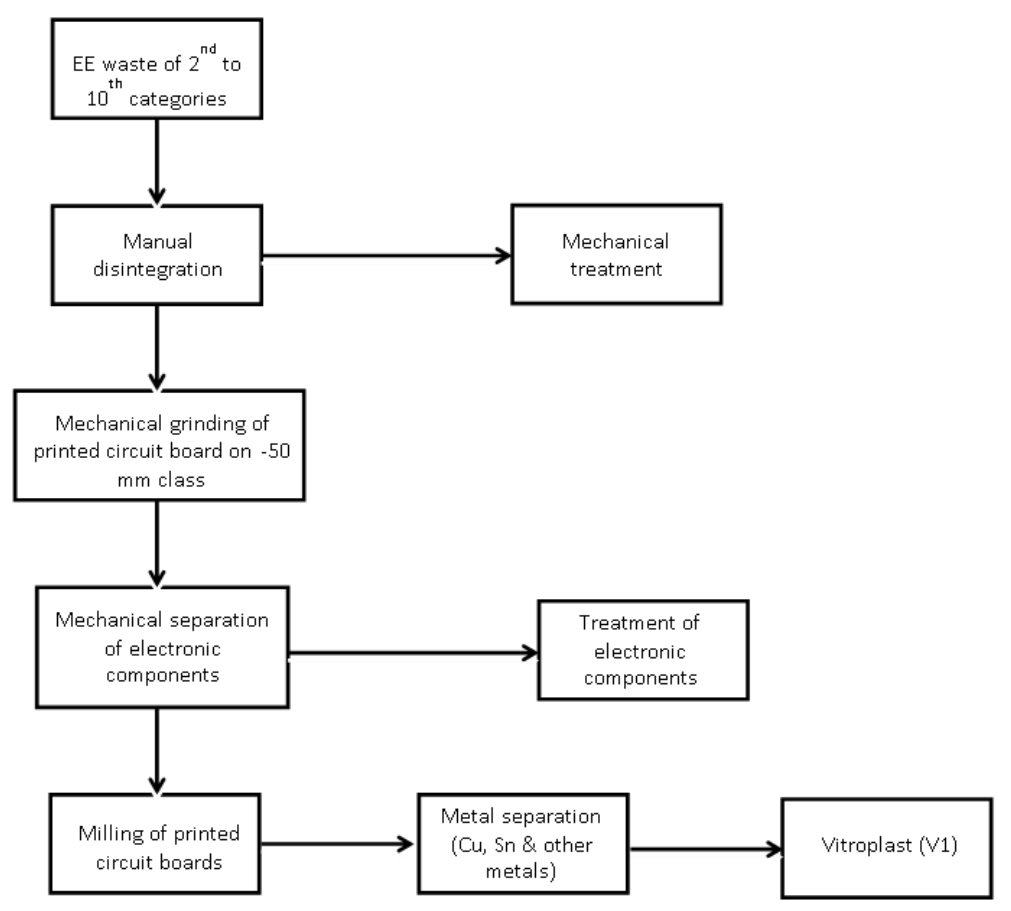

Figure 2. Technological procedure of Vitroplast separation from EE waste 


\section{Determination of strength}

Compression strengths were examined after 7 and 28 days of curing. Every reported data presents the average arithmetic value of 5 single measurements. Compression strength analysis was performed by using laboratory press of ZRMK type, Ljubljana 2, with measuring range of 400 i.e. $150 \mathrm{kN}$ with data recording of 1.0 i.e. $0.5 \mathrm{kN}$. The analysis of compression strength was performed according to EN 12390-3:2009 standard [19]. Furthermore, a series of swelling pressure tests were performed by using oedometer of $7.0 \mathrm{~cm}$ diameter and $20 \mathrm{~mm}$ sample height with the applied pressure of $5.0 \mathrm{kN} / \mathrm{m}^{2}$.

\section{Solubility of harmful compounds}

The study of impact of Vitroplast and concrete binding on release of harmful compounds in water was evaluated on the basis of leaching test according to standard procedure described in EN 12457-4:2002 [20]. The study was performed on the obtained Vitroplast sample (V1), concrete sample with mineral filler solely and concrete sample where $10 \%$ of mineral filler mass was substituted with sample V1. In order to investigate the solubility of harmful compounds, 28 days old samples of concrete were grinded manually with the pestle and mortar on $-20 \mathrm{~mm}$ class and dissolved in water for the following 24 hours with stirring by using mixer IKA ${ }^{\circledR} \mathrm{KS} / 130$. The mass ratio of water and dry compound in dissolving procedure exceeded 10:1. Analysis of eluent was performed by atomic absorption spectrophotometer Perkin Elmer Analyst 800 and UV/VIS spectrophotometer HACH DR5000.

\section{RESULTS AND DISCUSSION}

The addition of plastic materials influences many properties of fresh and solidified concrete, but the strength is probably the most important one. Therefore, the focus of the research was to determine concrete strength in solidification phase, after 7 days solidification and after 28 days of solidification (i.e. solidified concrete). A finely granulated and homogenized sample of concrete amounting of 100 to $120 \mathrm{~kg}$ was taken from an industrial pilot plant. The sample was equal in every part i.e. equal for every probe. The results of the analysis of strength of probationary bodies are shown with Figure 3.

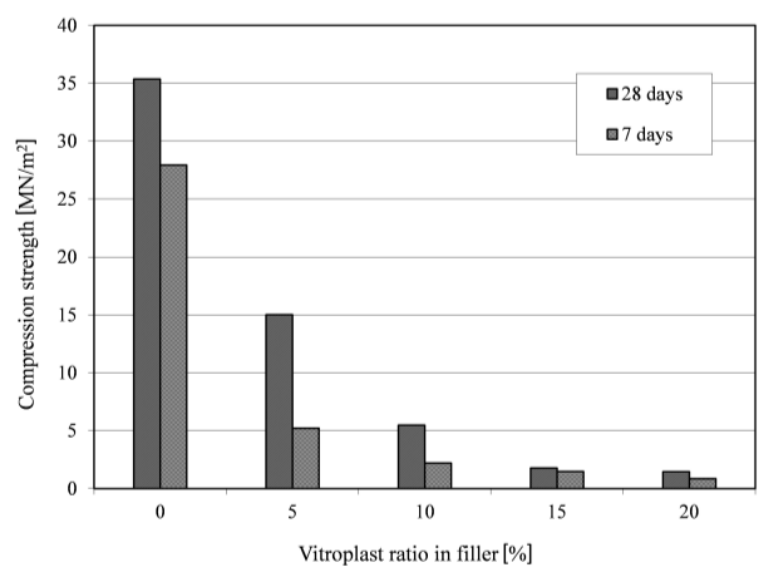

Figure 3. The influence of Vitroplast ration on compression strength

Each reported data presents the arithmetic values of analysis of 5 probation bodies. It can be seen that the compression strength of used concrete solidified in 28 days exceeds $35.36 \mathrm{MN} / \mathrm{m}^{2}$. Also a significant decrease of compression strength of solidified concrete 
was observed when a part of the filler was substituted by Vitroplast. By incorporating 5\% of mineral filler with Vitroplast after 28 days of ageing compression, strength decreased for $57.53 \%$ (Table 1).

Table 1. The influence of Vitroplast content on concrete strength

\begin{tabular}{ccc}
\hline \multirow{3}{*}{$\%$ of Vitroplast } & \multicolumn{2}{c}{ Decrease of compression strength [\%] } \\
\cline { 2 - 3 } & \multicolumn{2}{c}{ Age (days) } \\
\cline { 2 - 3 } & 7 & 28 \\
\hline 0 & 0 & 0 \\
5 & 81.31 & 57.53 \\
10 & 92.09 & 84.49 \\
15 & 94.72 & 94.98 \\
20 & 96.92 & 95.90 \\
\hline
\end{tabular}

By further addition of Vitroplast the strength still decrease, but slower. Wang et al. [1] published results which imply on strength decrease, but experiments were performed with significantly lower portion of Vitroplast and with about double ration of cement and filler. The almost equal value of compression strength found in samples with $15 \%$ of Vitroplast after 7 and 28 days of solidification evidence inhibition of the solidification process.

The results of volumetric weight are shown on Figure 4. The significant decrease of volumetric weight from $2.313 \mathrm{~g} / \mathrm{cm}^{3}$ up to $1.892 \mathrm{~g} / \mathrm{cm}^{3}$ can be observed if $20 \%$ of filler was substituted by Vitroplast.

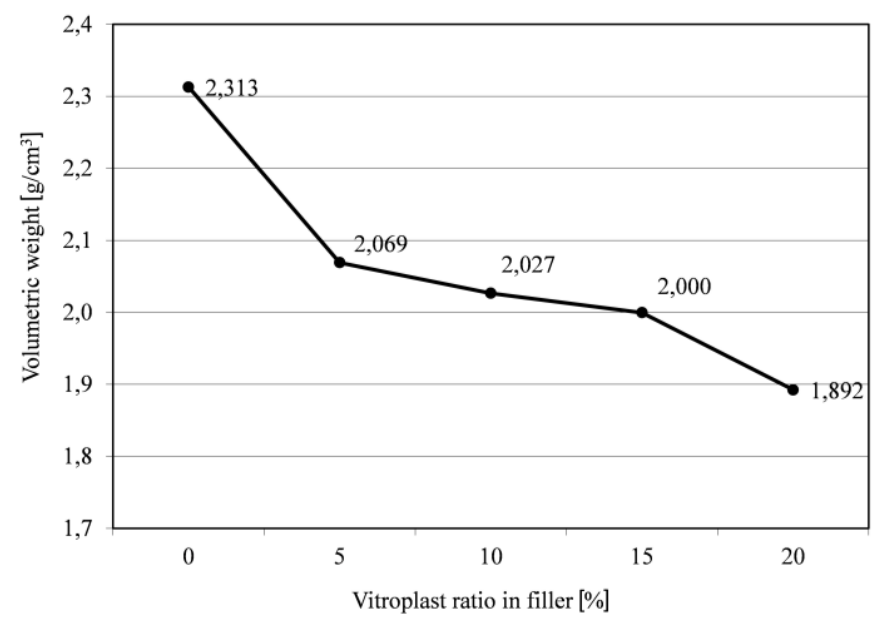

Figure 4. The influence of Vitroplast ration on volumetric value

In order to determine leaching of hazardous compounds the analysis of eluents was performed. The results are shown in Table 2. It can be seen that $\mathrm{As}, \mathrm{Cd}, \mathrm{Cu}, \mathrm{Cr}$ and DOC were encapsulated, i.e. measured values have found to be below the limits for inert waste prescribed by Law [21]. Also it was noticed that concentration of mercury was decreased on the level which is permitted for non-hazardous waste while lead is mobilized on the value of $1.62 \mathrm{ppm}$ as opposed from data published in literature [6]. Regarding fluorine content from the results obtained (Table 2.) it can be seen that concrete by itself causes some kind of chemical reaction so the content of fluorine is higher in the mixture made of concrete and Vitroplast. 
Table 2. Comparison results of eluent analysis

\begin{tabular}{ccccccc}
\hline & \multicolumn{3}{c}{ Sample } & \multicolumn{3}{c}{ Limitation value $^{*}(\mathrm{~L} / \mathrm{S}=10 / 1)^{* *}$} \\
\hline \multirow{2}{*}{ Parameter } & \multirow{2}{*}{$\mathrm{V} 1$} & $\begin{array}{c}\text { Concrete } \\
\text { V1 }\end{array}$ & $\begin{array}{c}\text { Concrete } \mathrm{w} \\
\text { V1 }\end{array}$ & $\begin{array}{c}\text { Inert } \\
\text { waste }\end{array}$ & $\begin{array}{c}\text { Non-hazardous } \\
\text { waste }\end{array}$ & $\begin{array}{c}\text { Hazardous } \\
\text { waste }\end{array}$ \\
\hline $\mathrm{As}(\mathrm{ppb})$ & 1.41 & $<\mathrm{dl}$ & $<\mathrm{dl}$ & 0.5 & 2 & 25 \\
$\mathrm{Ba}(\mathrm{ppm})$ & 8.69 & 7.16 & 8.05 & 20 & 100 & 300 \\
$\mathrm{Cd}(\mathrm{ppb})$ & 66 & 0.7 & $<\mathrm{dl}$ & 0.04 & 1 & 5 \\
$\mathrm{Cr}(\mathrm{ppm})$ & $<\mathrm{dl}$ & $<\mathrm{dl}$ & $<\mathrm{dl}$ & 0.5 & 10 & 70 \\
$\mathrm{Cu}(\mathrm{ppm})$ & 1.57 & 0.69 & 0.95 & 2 & 50 & 100 \\
$\mathrm{Hg}(\mathrm{ppb})$ & 0.6 & 0.05 & 0.18 & 0.01 & 0.2 & 2 \\
$\mathrm{Mo}(\mathrm{ppm})$ & $<\mathrm{dl}$ & $<\mathrm{dl}$ & $<\mathrm{dl}$ & 0.5 & 10 & 30 \\
$\mathrm{Ni}(\mathrm{ppm})$ & 0.48 & 0.96 & 0.99 & 0.4 & 10 & 40 \\
$\mathrm{~Pb}(\mathrm{ppm})$ & $<\mathrm{dl}$ & 0.63 & 1.62 & 0.5 & 10 & 50 \\
$\mathrm{Se}(\mathrm{ppm})$ & 0 & 0 & 0 & 0.1 & 0.5 & 7 \\
$\mathrm{Zn}(\mathrm{ppm})$ & 0.37 & 0.34 & 0.45 & 4 & 50 & 200 \\
$\mathrm{Cl}(\mathrm{ppm})$ & 400 & 360 & 340 & 800 & 15,000 & 25,000 \\
$\mathrm{~F}(\mathrm{ppm})$ & $<\mathrm{dl}$ & 2.8 & 4.9 & 10 & 150 & 500 \\
$\mathrm{SO}{ }_{4}^{2-}(\mathrm{ppm})$ & $<\mathrm{dl}$ & $<\mathrm{dl}$ & $<\mathrm{dl}$ & 1,000 & 20,000 & 50,000 \\
$\mathrm{Phenols} \mathrm{(ppm)}$ & 354 & 20.2 & 28.2 & 1 & - & - \\
$\mathrm{DOC}(\mathrm{ppm})$ & 3,381 & 78.39 & 207.1 & 500 & 800 & 1,000 \\
$\mathrm{TDS}(\mathrm{ppm})$ & 1,508 & 16.84 & 18.99 & 4,000 & 60,000 & 10,000 \\
\hline "L
\end{tabular}

*Limitation values for disposal on particular landfill categories according to regulations [21]

** Mass ratio of solid and water during solvation

The swelling was noticed with the ratio of vitroplast of 5, 10 and $15 \%$ but not when $20 \%$ of vitroplast was implemented. Moreover, in preliminary tests the average swelling of $5.4 \%$ was noticed. The pressure of swelling was determined by oedometric experiment by applying pressure of $15-20 \mathrm{kN} / \mathrm{m}^{2}$ (Figure 5). The figure shows the difference of height change in $2.0 \mathrm{~cm}$ thick sample of mixture and Vitroplast in the ration of 9:1 with water/cement factor of 0.38 pressed with $5 \mathrm{kN} / \mathrm{m}^{2}$.

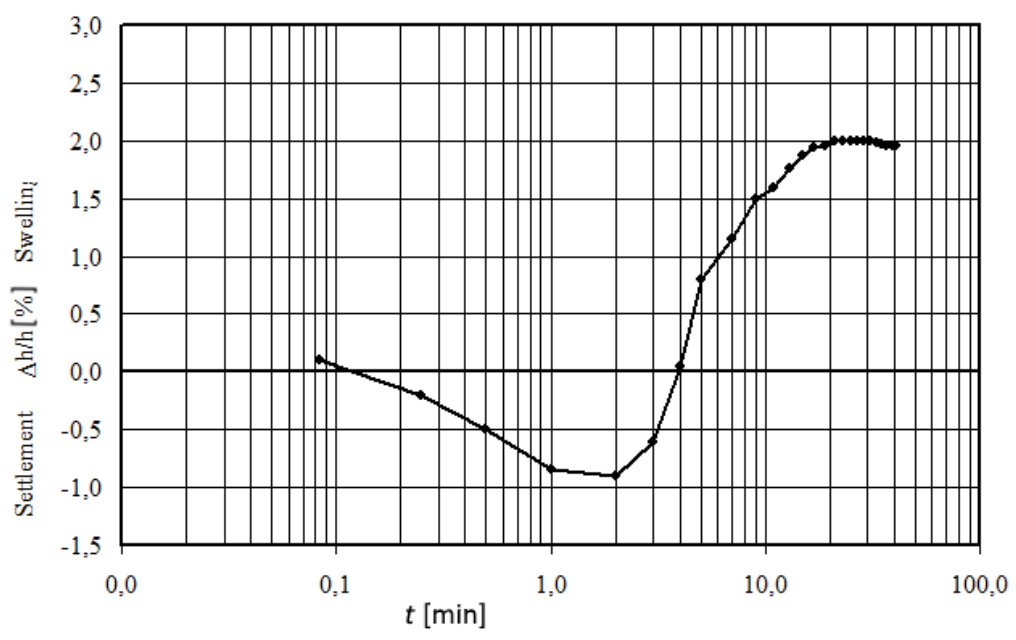

Figure 5. Swelling dynamics of the cement and vitroplast mixture ( $h$-height of sample)

It has to be emphasized that by the application of a constant ratio of water and cement with the addition of Vitroplast in fresh cement were obtained properties of dry mixture 
which are less appropriate for commercial application. This effect can probably be assigned to the larger specific surface of Vitroplast, i.e. to its low granulometric composition (Figure 6).

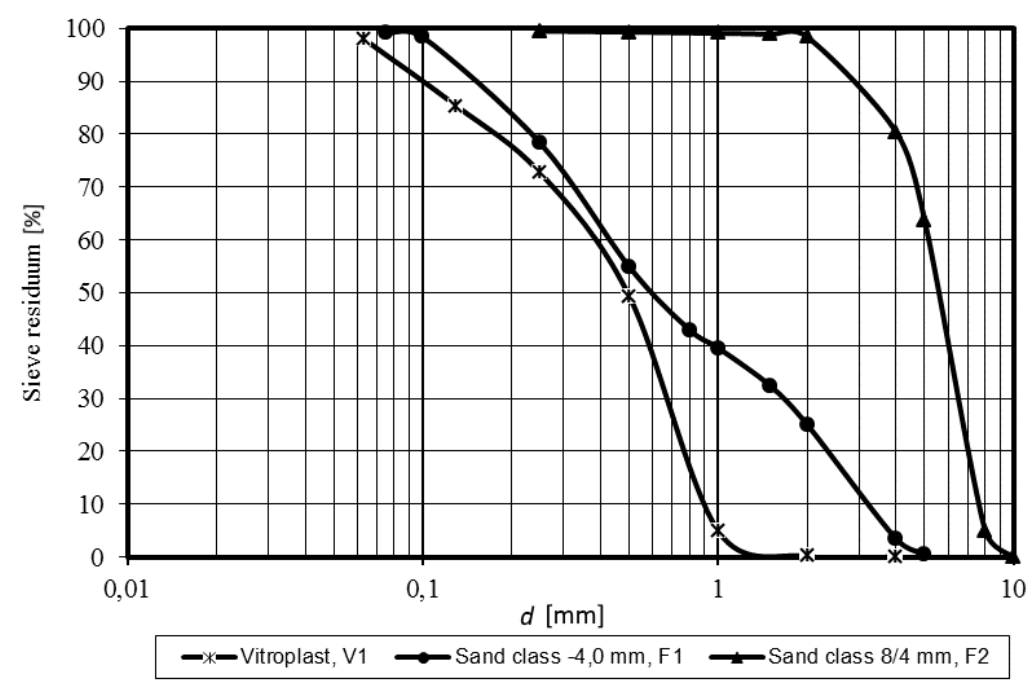

Figure 6. Granulometric composition of mineral fillers and Vitroplast

\section{CONCLUSION}

The possibilities for incorporation of Vitroplast in concrete mixture in manufacturing of concrete products as well as disposal of most hazardous part of EE waste were investigated. By imitation of the procedure of concrete production aimed for manufacturing of concrete products, the increase of Vitroplast in concrete mixture, significantly decreases its strength. By using 5\% of Vitroplast and with variations of cement and water rations, the possibility for achieving satisfactory strengths were given. The analysis of eluent shows that by implementation of Vitroplast in concrete, harmful compounds were encapsulated in large extent. The decrease of volumetric weight value opens the possibilities for new applications and use. From the other hand, the swelling can limit the use of concrete mixture. It has to be emphasized that application of constant ratio of water and cement with addition of vitroplast in fresh cement made properties of dry mixture which is less appropriate for commercial application. This effect can be probably assigned to larger specific surface of vitroplast, i.e. its low granulometric composition.

Recommendation for further research would definitely be the determination of compressive strength in the range of Vitroplast ratio up to $5 \%$. Also it would be interesting to find out of tensile strengths of samples and other properties such as porosity, freezing resistance and workability of fresh concrete.

\section{NOMENCLATURE}

\begin{tabular}{ll}
\multicolumn{2}{c}{ Abbreviations } \\
DOC & Dissolved Oxygen Concentration \\
TDS & Total Dissolved Solids \\
w & with \\
w/o & without \\
dl & detection limit \\
L/S & Liquid/Solid
\end{tabular}




\section{REFERENCES}

1. Wang, R., Zhang, T. and Wang, P., Waste Printed Circuit Boards Non-metallic Powder as Admixture in Cement Mortar, Mater Struct, Vol. 45, No. 10, pp 1439-1445, 2012, http://dx.doi.org/10.1617/s11527-012-9843-0

2. Luda, M. P., Recycling of Printed Circuit Boards. In: Kumar S. (Ed.): Integrated Waste Management - Volume II, InTech, Shanghai, China, 2011.

3. Chao, G., Hui, W., Wei, L., Jiangong, F. and Xin, Y., Liberation Characteristic and Physical Separation of Printed Circuit Board (PCB), Waste Manage, Vol. 31, No. 9-10, pp 2161-2166, 2011, http://dx.doi.org/10.1016/j.wasman.2011.05.011

4. Oguchi, M., Murakami, S., Sakanakura, H., Kida, A. and Kameya, T., A Preliminary Categorization of End-of-life Electrical and Electronic Equipment on Secondary Metal Resources, Waste Manage, Vol. 31, No. 9-10, pp 2150-2160, 2011, http://dx.doi.org/10.1016/j.wasman.2011.05.009

5. Ban, B. C., Song, J. Y., Lim, J. Y., Wang, J. Y., An, K. G. and Kim, D. S., Studies on the Reuse of Waste Printed Circuit Board as an Additive for Cement Mortar, J Environ Sci Heal A, Vol. 40, No. 3, pp 645-656, 2005, http://dx.doi.org/10.1081/ESE-200046618

6. Niu, X. and Li, Y., Treatment of Waste Printed Wire Boards in Electronic Waste for Safe Disposal, J Hazard Mater, Vol. 145, No. 3, pp 410-416, 2007, http://dx.doi.org/10.1016/j.jhazmat.2006.11.039

7. Zoeteman, B. C. J., Krikke, H. R. and Vanselaar, J., Handling WEEE Waste Flows: on the Effectiveness of Producer Responsibility in a Globalizing World, Int J Adv Manuf Tech, Vol. 47, No. 5-8, pp 415-436, 2010, http://dx.doi.org/10.1007/s00170-009-2358-3

8. Sohaili, J., Muniyandi, S. K. and Mohamad, S. S., A Review on Printed Circuit Boards Waste Recycling Technologies and Reuse of Recovered Nonmetallic Materials, IJSER, Vol. 3, No. 2, pp 1-7, 2012.

9. Veit, H. M., Bernardes, A. M., Ferreira, J. Z., Tenorio, J. A. S. and Malfatti, C. F., Recovery of Copper from Printed Circuit Boards Scraps by Mechanical Processing and Electrometallurgy, J Hazard Mater, Vol. 137, No. 3, pp 1704-1709, 2006, http://dx.doi.org/10.1016/j.jhazmat.2006.05.010

10.Huang, K., Guo, J. and Xu, Z., Recycling of Waste Printed Circuit Boards: A Review of Current Technologies and Treatment Status in China, J Hazard Mater, Vol. 164, No. 2 3, pp 399-408, 2009, http://dx.doi.org/10.1016/j.jhazmat.2008.08.051

11.Anić Vučinić, A., Vujević, D., Premur, V., Lilek, H., Blažić, D., Lenček, S., Mikić, A. and Kaniški, M., Characterization and the Possibilities of the Waste Management Generated in the Printed Circuit Boards Reuse Process, Proceedings of $12^{\text {th }}$ International Symposium of Waste Management, Zagreb, pp 1-10, October 29-30, 2102.

12.Mou, P., Xiang, D. and Duan, G., Products Made from Nonmetallic Materials Reclaimed from Waste Printed Circuit Boards, Tsinghua SciTechnol, Vol. 12, No. 3, pp 276-283, 2007, http://dx.doi.org/10.1016/S1007-0214(07)70041-X

13.Batayneh, M., Marie, I. and Asi, I., Use of Selected Waste Materials in Concrete Mixes, Waste Manage, Vol. 27, No. 12, pp 1870-1876, 2007, http://dx.doi.org/10.1016/j.wasman.2006.07.026

14.Siddique, R., Khatib, J. and Kaur, I., Use of Recycled Plastic in Concrete: A Review, Waste Manage, Vol. 28, No. 10, pp 1835-1852, 2008, http://dx.doi.org/10.1016/j.wasman.2007.09.011

15.Vardaka, G., Thomaidis, K., Leptokardis, C. and Tsimas, S., Use of Steel Slag as Coarse Aggregate for the Production of Pervious Concrete, JSDEWES, Vol. 2, No. 1, pp 30-40, 2014, http://dx.doi.org/10.13044/j.sdewes.2014.02.0003

16.Zeng, X., Zheng, L., Xie, H., Lu, B., Xia, K., Chao, K., Li, W., Yang, J., Lin, S. and Li, J., Current Status and Future Perspective of Waste Printed Circuit Boards Recycling, 


ProcedEnviron Sci, Vol. 16, pp 590-597, 2012,
http://dx.doi.org/10.1016/j.proenv.2012.10.081

17.Zhu, P., Chen, Y., Wang, L. Y. and Zhou, M., Treatment of Waste Printed Circuit Board by Green Solvent using Ionic Liquid, Waste Manage, Vol. 32, No. 10, pp 1914-1918, 2012, http://dx.doi.org/10.1016/j.wasman.2012.05.025

18.EN 12390 Testing Hardened Concrete - Part 2: Making and Curing Specimens for Strength Tests, CEN, Brussels, Belgium, 2009.

19.EN 12390 Testing Hardened Concrete - Part 3: Compressive Strength of Test Specimens, CEN, Brussels, Belgium, 2009.

20.EN 12457 - 4 Characterization of Waste - Leaching - Compliance Test for Leaching of Granular Waste Materials and Sludges - Part 4: One Stage Batch Test at a Liquid to Solid Ratio of 10 1/kg for Materials with Particle Size below $10 \mathrm{~mm}$ (without or with size reduction), CEN, Brussels, Belgium, 2002.

21. Ordinance on the Methods and Conditions for the Landfill of Waste, Categories and Operational Requirements for Waste Landfills, Official Gazette 117/07, 111/11, http://narodne-novine.nn.hr/default.aspx, [Accessed: 19-December-2013] 